\title{
Ecological trap for Cnemidophorus ocellifer Spix 1825 (Squamata: Teiidae) during removal of vegetation
}

\author{
Lucas Bezerra de Mattos Brito ${ }^{1 *}$ \\ Igor Joventino Roberto ${ }^{1,2}$ \\ Paulo Cascon ${ }^{1}$
}

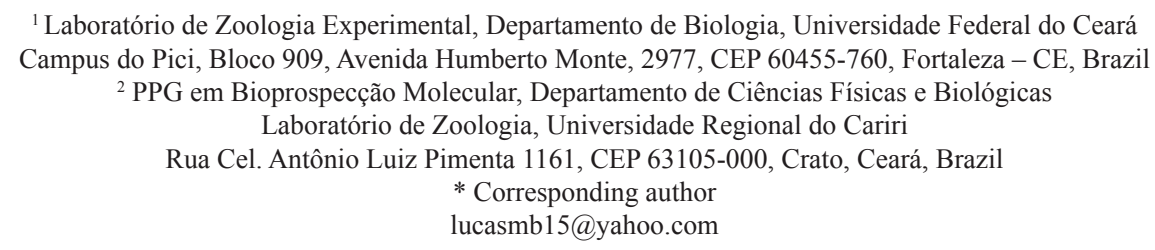

Submetido em 01/02/2012

Aceito para publicação em 27/06/2012

\section{Resumo}

Armadilha ecológica para Cnemidophorus ocellifer Spix 1825 (Squamata: Teiidae) durante supressão de vegetação. Os animais devem prever condições futuras de acordo com as pistas ambientais do presente. Quando os hábitats são rapidamente modificados, esses sinais podem não refletir a real qualidade do ambiente, levando a uma diminuição da aptidão do indivíduo e de sua população. Durante atividade de resgate e afugentamento de fauna no litoral do Rio Grande do Norte, Brasil, observamos evidências de uma armadilha ecológica para o lagarto Cnemidophorus ocellifer. Sugerimos algumas ações que podem minimizar o impacto de atividades de desmatamento sobre lagartos, dentre as quais: i) melhor planejamento antes de proceder com desmatamento; e ii) captura e soltura de lagartos em locais adequados.

Palavras-chave: Heliófilo; Lagarto; Litoral; Resgate de fauna

\section{Abstract}

Animals must anticipate future conditions according to current environmental clues. When habitats are rapidly modified, these signs may not reflect the actual environmental quality, leading to a decreased fitness of an individual and its population. During an activity of faunal rescue and scaring away in the coast of Rio Grande do Norte, Brazil, evidence of an ecological trap for the lizard Cnemidophorus ocellifer was observed. We suggest some actions which can minimize the impact of vegetation removal activities on lizards, such as: i) better planning before proceeding with deforestation; and ii) capture and release of lizards in appropriate locations.

Key words: Coast; Fauna rescue; Heliophile; Lizard 
The behavior of animals is determined by their evolutionary past (QUEIROZ; WIMBERGER, 1993). Environmental clues (e.g., light intensity, canopy cover, spatial heterogeneity) are used by individuals to evaluate environmental quality (e.g., food abundance, reproductive and basking sites, predator density) in current and future time frames (KOKKO; SUTHERLAND, 2001; BATTIN, 2004; ROBERTSON; HUTTO, 2006). When habitats are rapidly modified, usually due to human action, environmental signs can lead animals to choose inadequate areas, thus decreasing their overall fitness. Such habitats are known as ecological traps (SCHLAEPFER et al., 2002), a concept which has been frequently associated to edge effect and its impact on birds (FLASPOHLER et al., 2001; SHOCHAT et al., 2005; WELDON; HADDAD, 2005), also demonstrated or suggested with regard to vertebrates (e.g., PELICICE; AGOSTINHO, 2008) and invertebrates (e.g., HORVÁTH et al., 2007; HEDIN et al., 2008). Among reptiles, ecological traps have been suggested for turtles, which were mistakenly attracted to artificial lights, and lacertid lizards, Acanthodactylus beershebensis (WITHERINGTON, 1997; HAWLENA et al., 2010). We report here evidence from field observation which indicates a case of ecological trap for Cnemidophorus ocellifer during removal of vegetation to implement transmission lines in Northeastern Brazil. Whiptail lizard C. ocellifer is a heliophilic wide-foraging species which is mostly active on sandy soils and under direct sunlight incidence (MESQUITA; COLLI, 2003); it's frequently found in disturbed areas.

From May $27^{\text {th }}$ to July $14^{\text {th }} 2011$ we participated in a fauna rescue program, monitoring the herpetofauna during deforestation of a restinga environment through earthwork procedures (Figure 1A-C) to implement

FIGURE 1: Deforestation of a restinga habitat in Rio Grande do Norte, Northeastern Brazil, and its impact on the fauna. A - Area before earthwork procedures; $\mathrm{B}$ - area with remaining vegetation patches after initial removal through tractor; $\mathrm{C}-$ area after the conclusion of vegetation removal; D - A specimen of Cnemidophorus ocellifer killed by the tractor.

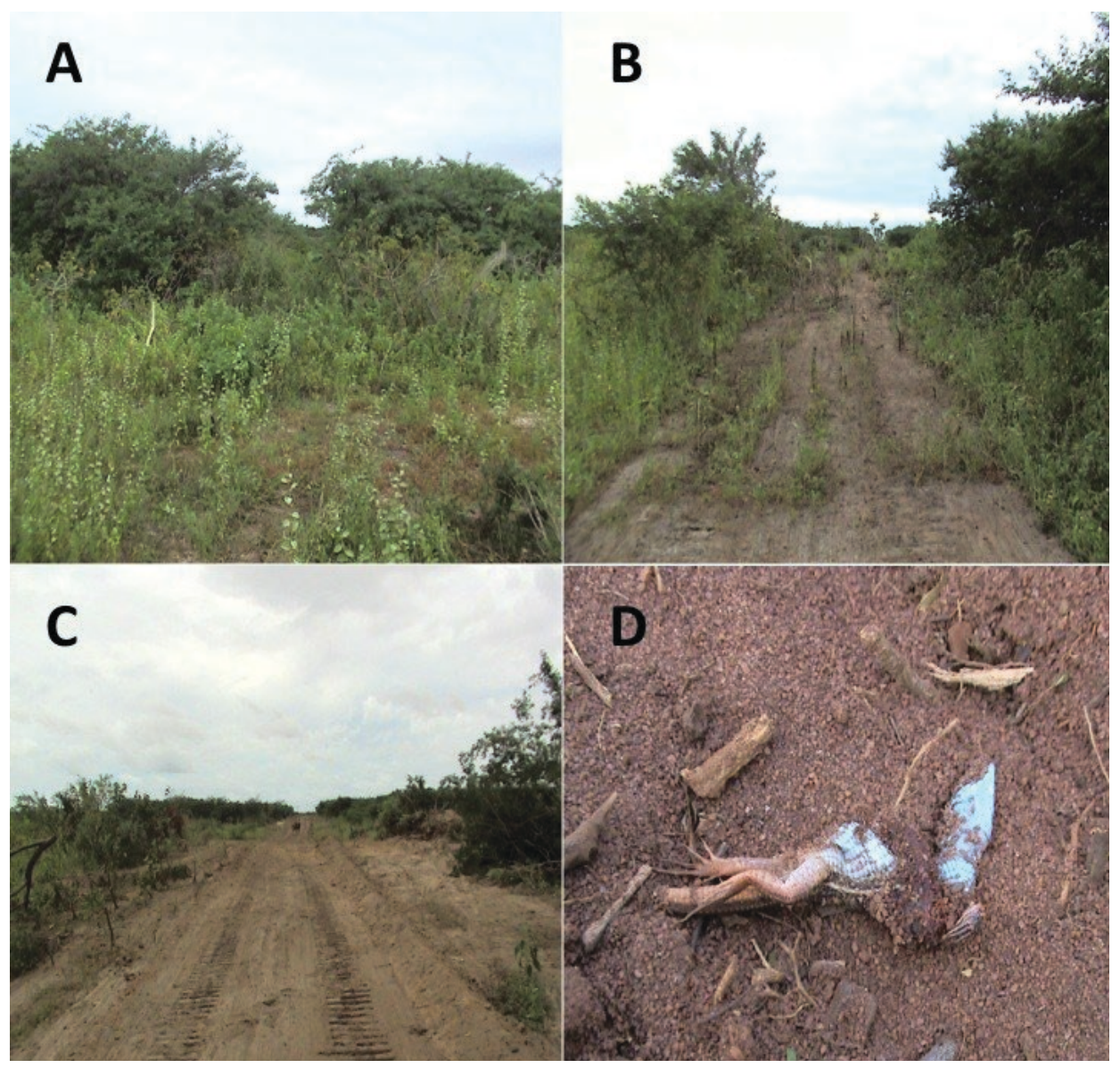


transmission lines. The study was carried out in the towns of Guamare $\left(05^{\circ} 09^{\prime} 30.9^{\prime \prime} \mathrm{S}, 36^{\circ} 27^{\prime} 05.0^{\prime \prime} \mathrm{W}\right)$ and Pendencias (05'18'46.9'S, 3641'34.7'W), Rio Grande do Norte, Northeastern Brazil. Restingas consist of a mosaic of different plant communities (herbaceous, shrubby, or arboreal ones), which occurs in sandy plains formed in the late Quaternary, found along most of the Brazilian coast (SCARANO, 2002). Notes were taken on scared away, rescued, or killed individuals. The cleared area consisted of a semi-straight line about $5 \mathrm{~m}$ in width. Every $450 \mathrm{~m}$, this line was cut off into "squares" of 20 x $20 \mathrm{~m}$. The area along the "line" had been previously cleared (nearly six months) (Figure 1A), thus creating a kind of edge habitat where sunlight incidence was higher than that of the "square" areas, which had not been previously cleared, and the surrounding environment.

Within this period, 282 specimens of $C$. ocellifer were observed, of which 216 were alive (163 scared away and 53 rescued) and 66 were dead. When the tractor was removing vegetation, a greater abundance of individuals (both dead and alive) were found along "line" areas $(\mathrm{N}=118)$ than in "square" areas $(\mathrm{N}=37)$ (Figures 1D and 2). Due to their length, the deforestation of these lines can last more than one day; therefore, C. ocellifer (Figure 2) was frequently found in the remaining vegetation patches from one day to another. In this situation, when work began the following day, relatively more individuals were found, both dead and alive (overall values: 11-17 individuals in "lines" with vegetation patches from the previous day; 1-7 individuals in "lines" without vegetation patches). Since there was no specific experimental design aimed at this issue and because there was a daily variation in the amount of hours of vegetation removal and total area suppressed, as well as occasional technical problems with the tractor, we chose not to analyze the data statistically due to the wide variety of potential biases. Nevertheless, field observations suggested that vegetation removal prior to planned deforestation, as well as the remaining vegetation patches from one day to another, create areas with suitably high sunlight incidence, which attract $C$. ocellifer and other heliophilic species from the region (e.g., Vanzosaura rubricauda), therefore, making them more vulnerable to be run over by the tractor. These observations provide evidence indicating the occurrence of an ecological trap on the population of $C$. ocellifer under study.

FIGURE 2: A specimen of Cnemidophorus ocellifer observed under vegetation patches during deforestation of a restinga habitat in Rio Grande do Norte, Northeastern Brazil.

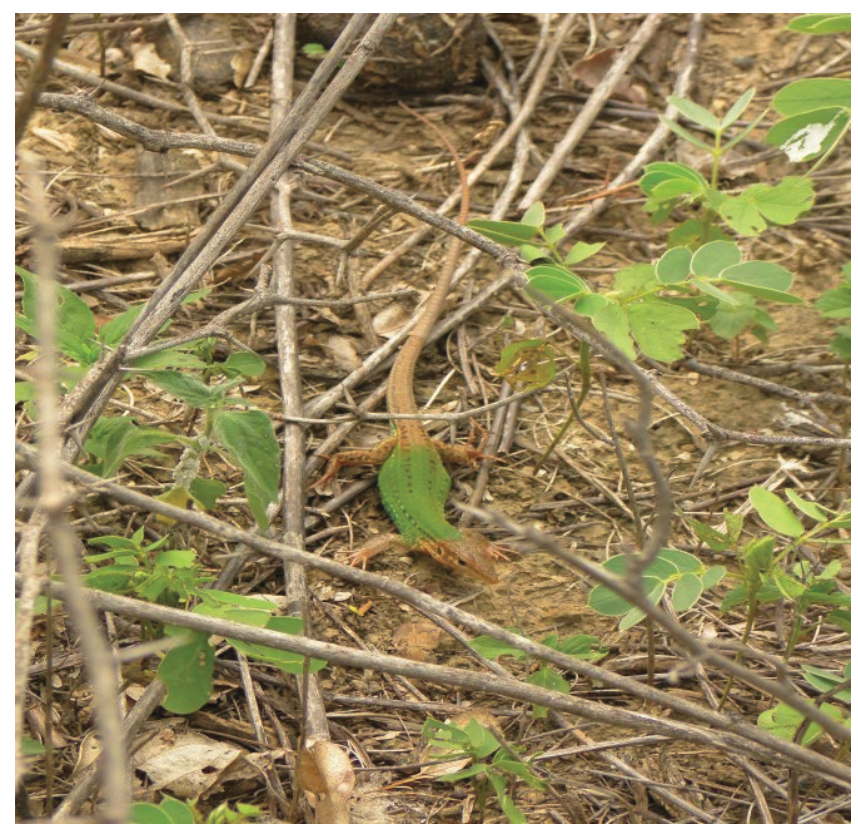

Based on field observations, a potential ecological trap has been identified; considering this, we believe lizard mortality may be minimized if: i) vegetation removal is performed for a longer period of time before planned deforestation begins, thus allowing vegetation to grow and eliminating or, at least, minimizing the "edge effect"; ii) tractors only start earthwork in a certain area when it can be concluded within a days' work, instead of leaving vegetation patches to be removed from one day to the other; and iii) lizards are trapped and relocated to adequate areas before earthwork procedures are resumed long afterwards.

If our hypotheses are correct, this constitutes the first report on an ecological trap for neotropical lizards. Because of their negative effects on population fitness, ecological traps can lead to local species extinction if they aren't detected and managed in time (GILROY; SUTHERLAND, 2007). Considering that earthwork procedures are situated in time and space, this doesn't seem to be the case for the $C$. ocellifer population under 
study. Nevertheless, it's important that conservationists and environmental agencies become aware of its existence and provide a close monitoring of local populations, in order to investigate how species are behaving with regard to this potential edge habitat. We agree with Pelicice and Agostinho (2008) when they claim that, although there's a need for an experimental design to effectively test ecological trap hypotheses, researchers shouldn't wait for it to report situations where native populations are negatively impacted.

\section{Acknowledgements}

The authors would like to thank: two anonymous referees, for suggestions that greatly improved the manuscript; and Sertões Consultoria Ambiental, for financial and logistical support.

\section{References}

BATTIN, J. When good animals love bad habitats: ecological traps and the conservation of animal population. Conservation Biology, Washington, v. 18, n. 6, p. 1482-1491, 2004.

FLASPOHLER, D. J.; TEMPLE, S. A.; ROSENFIELD, R. N. Species-specific edge effects on nest success and breeding bird density in a forested landscape. Ecological Applications, Ithaca, v. 11, n. 1, p. 32-46, 2001.

GILROY, J. J.; SUTHERLAND, W. J. Beyond ecological traps: perceptual errors and undervalued resources. Trends in Ecology and Evolution, London, v. 22, n. 7, p. 351-356, 2007.

HAWLENA, D.; SALTZ, D.; ABRAMSKY, Z.; BOUSKILA, A. Ecological trap for the desert lizard caused by anthropogenic changes in habitat structure that favor predator activity. Conservation Biology, Washington, v. 24, n. 3, p. 803-809, 2010.

HEDIN, J.; ISACSSON, G.; JONSELL, M.; KOMONEN, A. Forest fuel piles as ecological traps for saproxylic beetles in oak. Scandinavian Journal of Forest Research, Knivsta, v. 23, p. 348$357,2008$.
HORVÁTH, G.; MALIK, P.; KRISKA, G.; WILDERMUTH, H Ecological traps for dragonflies in the cemetery: the attraction of Sympetrum species (Odonata: Libellulidae) by horizontally polarizing black gravestones. Freshwater Biology, Singapore, v. 52, p. 1700-1709, 2007.

KOKKO, H.; SUTHERLAND, W.J. Ecological traps in changing environments: ecological and evolutionary consequences of a behaviorally mediated Allee effect. Evolutionary Ecology Research, Tucson, v. 3, p. 537-551, 2001

MESQUITA, D. O.; COLLI, G. R. The ecology of Cnemidophorus ocellifer (Squamata, Teiidae) in a Neotropical Savanna. Journal of Herpetology, Salt Lake City, v. 37, n. 3, p. 498-509, 2003.

PELICICE, F. M; AGOSTINHO, A. A. Fish-passage facilities as ecological traps in large neotropical rivers. Conservation Biology, Washington, v. 22, n. 1, p. 180-188, 2008.

QUEIROZ, A.; WIMBERGER, P. H. The usefulness of behavior for phylogeny estimation: levels of homoplasy in behavioral and morphological characters. Evolution, New Jersey, v. 47, n. 1, p. 46-60, 1993.

ROBERTSON, B. A.; HUTTO, R. L. A framework for understanding ecological traps and an evaluation of existing evidence. Ecology, Ithaca, v. 87, n. 5, p. 1075-1085, 2006

SCARANO, F. R. Structure, function and floristic relationships of plant communities in stressful habitats marginal to the Brazilian Atlantic Rainforest. Annals of Botany, Oxford, v. 90, p. 517-524, 2002.

SCHLAEPFER, M. A.; RUNGE, M. C.; SHERMAN, P. W. Ecological and evolutionary traps. Trends in Ecology and Evolution, London, v. 17, n. 10, p. 474-480, 2002.

SHOCHAT, E.; PATTEN, M. A.; MORRIS, D. W.; REINKING, D. L.; WOLFE, D. H.; SHERROD, S. K. Ecological traps in isodars: effects of tallgrass praire management on bird nest success. Oikos, Lund, v. 111, p. 159-169, 2005.

WELDON, A. J.; HADDAD, N. M. The Effect of pacth shape on indigo buntings: evindence for an ecological trap. Ecology, Ithaca, v. 86, n. 6, p. 1422-1431, 2005.

WITHERINGTON, B. E. The problem of photopollution for sea turtles and other nocturnal animals. In: CLEMMONS, J. R.; BUCHOLZ, R. (Ed.). Behavioral Approaches to Conservation in the Wild. Cambridge: Cambridge University Press, 1997. p. 303-328. 